maticheskii stroi russkogo iazyka v sopostavlenii s slovatskim (vol. 1, 1954; vol. 2, 1960 ), perhaps the best synchronic treatment of Russian available.

The present volume is a collection of thirty-two articles (twenty-one in Russian, the others in German, French, and English), reproduced by photo-offset from the various journals, Festschrifts, and other collective volumes in which they originally appeared, with a three-page laudatory preface by Henrik Birnbaum. They range in date from 1935 to 1970, and in subject matter from the ambitious Versuch einer Typologie der slavischen Sprachen-a paper which stimulated a great many studiesto an analysis of a sixteenth-century Russian obscene curse recorded by the Austrian diplomat Baron Herberstein (who had grown up in Carinthia and knew Slovene). Some articles deal with quite technical linguistics (such as the argumentation proposing to analyze the "long soft" $\check{s} \check{c}$ and $\check{z} \check{z}$ of Russian as underlying $s \check{c}$ and $z \check{z}$ ), while other works use linguistic data to illuminate cultural problems (for example, the question of the possible Irish missionary background to Moravian Christianity before Cyril's arrival). Unlike many contemporary linguists, Isačenko is not given to theorizing without concrete data. The reader who is dissatisfied with Isačenko's methodological treatment of a problem, or with the conclusions, will find that Isačenko has already provided most of the material needed for an alternative analysis.

These articles are informative, useful, and stimulating; one is grateful that they have been made available in this volume. Alexander Isačenko was an extraordinarily influential teacher and scholar, with competence in a range of areas that can scarcely be matched by younger Slavists. One hopes that further volumes of his selected works will be printed.

Horace G. LunT Harvard University

\title{
A BIBLIOGRAPHY OF RUSSIAN WORD-FORMATION. By Dean S. Worth. Columbus, Ohio: Slavica Publishers, 1977. xliv, 317 pp. \$11.95, paper.
}

Having accumulated, after "several years of work on theoretical problems of Russian wor[d]-formation," about a thousand titles dealing with such topics as "derivational motivation, stem divisibility, productivity, the interrelations of semantic and phonological processes in derivation, morphophonemic phenomena like truncation, interfixation, and superposition, and so forth," the compiler felt the need to devise a classificatory framework for his material, a task "tantamount to defining the field of study itself." The effort "seemed to justify a new and more detailed search of the literature," and the result is this classified and cross-referenced listing of some three thousand works, preceded by a twelve-page table of contents (which "can be read as a typology of topics in Russian derivation"), a nine-page introduction, and twentyone pages of sources, and followed by a forty-six-page author index. The first several hundred publications are said to have had detailed annotations. This was discontinued because, among other reasons, "it was impossible (and in many cases, perhaps, unnecessary) to obtain all provincial Soviet publications for de visu examination." Unnecessary presumably because the title was thought to be sufficient for purposes of classification, with no value judgment intended. This is not always true, however. N. S. Avilova's "K voprosu o slovoobrazovatel'nykh tipakh russkogo glagola," given on page 243 under "Verbs, General Studies," deals exclusively with verbs in -stvovat' and should be listed under that suffix on page 142. "Structural Derivation in Russian," a dissertation listed on page 2 under "Monographic Studies," is primarily concerned with the derivation of complex sentences. The fullest coverage seems to be of work published in the Soviet Union (to mid-1973), which may have to do with the availability of the volumes, Slavianskoe iazykoznanie, ukazatel' literatury izdannoi $v$ SSSR 
$s 19 \ldots$ po $19 \ldots$ god. Thus under the suffix -nu- we find P. S. Sigalov's summary of Tedesco's important 1948 study in Language but not the article itself. Under -anuwe find a 1963 article by Sigalov but not Stender-Petersen's 1931 article in Zeitschrift für slavische Philologie. The two-page article by $S$. Korbe listed on page 66 turns out to be an abstract of an eight-page article by Charles Corbet published in volume 34 of Revue des études slaves.

Some may have preferred the shorter, critical bibliography containing Worth's personal assurance that the items listed actually exist and may be worth a librarian's effort to obtain. Nevertheless, the work before us is an impressive compilation. It lists ninety-nine $U$ chenye zapiski!

\section{Frank Y. Gladney University of Illinois at Urbana-Champaign}

SEMIOTICS OF CINEMA. By Jurij Lotman. Translated from the Russian and with a foreword by Mark E. Suino. Michigan Slavic Contributions, 5. Ann Arbor: Department of Slavic Languages and Literatures, University of Michigan, 1976. x, 106 pp. Paper.

Iurii Lotman's Semiotics of Cinéma is a graceful, deft, and essential primer-but not for the study of movies so much as for the systematic analysis of how meaning is made in movies. For some the study of how pictorial and verbal signs are used in a medium so entertaining, self-presentational, and experiential as film is destined to be abstruse; and the abrasive controversy that still surrounds the applicability of film semiotics to teaching or criticism reveals the suspicion that a "linguistics" of cinema is but another means of inflating and academizing what should, after all, remain "the movies," and not become another "discipline."

But movies are made of images, and images are "stand-ins" for whatever they represent. In semiotics, images that carry meaning are termed signs, and to say that such signs are pictorial and therefore obvious in meaning is not to say that they are unstructured and uncoded. In fact, in film circles, we have known since Kuleshov and Eisenstein that the signs in film images are both heavily (and often unconsciously) structured and coded. But as Lotman now points out more precisely, film images (shots) gain their meaning in two ways. First, film meaning can be termed positional, since film shots are never seen and understood in isolation but always adjacent to other shots. An image, for example, of a little girl playing with a ball followed by an image of an approaching car, as Kuleshov discovered, would produce the implication in a film that the child is endangered by the car, though danger would not otherwise be attributable to either shot. This, put simply, is the key to the inherent structure of what is called montage. But as we now know, film shots are also meaningful in their associational relationships, which is to say that any sign-say, the image of the car-gains specific meaning, or is "read," because it is a member of a mental set of "vehicles" and of a subset of "cars." Clearly, if the car were "readable" on the screen as a hot rod, it would be because viewers not only understand the image for what it is-a souped-up car made for speed-but also for what it is not, namely, a member of the mental set (or paradigm) of "remaining" cars which stand in "opposition" to the hot rod and hence give it meaning. From the standpoint of semiotics, it is in this way that films are made and understood, consciously or otherwise, as texts.

Needless to say, there is, despite its modest brevity, much more material in Lotman's book that is immediately useful in teaching and criticism for Slavicists interested in the modern period and for film scholars or enthusiasts. The original was published in Estonia in 1973 as Semiotika kino i problemy kinoestetiki; Mark Suino's complete, faithful, and competent translation and foreword (despite such neologisms as "irreal" 